DOI 10.31392/NPU-nc.series15.2021.8(139).01

Full Professor, Doctor of Science in Physical Education and Sport, Professor of the Football Department National University of Physical Education and Sport of Ukraine Andrey Osiptsov

Full Professor, Doctor of Science in Pedagogy, Professor of the Department of Physical Education, Sport and Health, Mariupol State University Igor Dub

Associate Professor, PhD in Physical Education and Sport, Associate Professor of the Department of Physical Therapy, Ergotherapy, Physical Education and Sport, Khmelnytskyi Institute of Social Technologies of University "Ukraine" Anatolii Kosholap

PhD in Physical Education and Sport, Associate Professor of the Department of Physical Education, Sport and Healt, Mariupol State University Alexander Vertel Associate Professor, PhD in Physical Education and Sport, Associate Professor of the Department of Physical Education, Sport and Healt, Mariupol State University Mykhailo Balychev Assistant of the Department of Physical Education, Sport and Health, Mariupol State University

\title{
COMPETITIVE PRACTICE IN FOREIGN CHILDREN'S AND YOUTH FOOTBALL
}

In the 1980s, experts from different countries with developed football, realizing that "street" football is a thing of the past, came to the conclusion that it is necessary to revise the system of training young talents and give children the opportunity to train and play according to their own rules i.e. to the "nature" of children's football. When licensing football clubs, the Union of European Football Associations (UEFA) defined the requirements for the development of training programs for young football players based on strategic tasks, where priority is given to the individual development of the player, and the achievement of sports results is secondary ("development first, then the result "). World experience shows that in order to create conditions for the gradual development of the diverse qualities of young players, it is necessary: firstly, to refuse to participate in official competitions up to 12 years old in order to focus on the quality and effectiveness of the training process aimed at individual development and training of a creative player; secondly, to conduct training sessions in a game form on a high emotional background with the obligatory consideration of age and individual characteristics of children. It is the application of the game method that is the key to effective learning, during which individual opportunities develop, game intelligence is formed, the foundations of the child's technical and tactical skills are laid, which in the future will determine the player's potential at a professional level.

Keywords: "nature" of children's football, Union of European Football Associations, official competitions, the effectiveness of the training process, game method.

В. Ніколаснко, А. Осіпцов, І. Дуб, А. Кошолап, О. Вертель, М. Баличев. Змагальна практика в зарубіжному дитячо-юнацькому футболі. У 1980-х роках фрахівці ряду країн з розвиненим футбболом, усвідомлюючи, що «вуличний» футбол йде в минуле, прийшли до висновку про необхідність перегляду системи навчання юних талантів і надати дітям можливість тренуватися та грати за їхніми власними правилами, тобто овернутися до «природи» дитячого футтболу. При ліцензуванні футбольних клубів Союз європейських футтбольних асоціацій визначив вимоги до складання програм з навчання юних футтболістів, засновані на вирішенні стратегічних завдань, де пріоритет віддається індивідуальному розвитку гравия, а досягнення спортивних результатів відходить на другий план ( "спочатку розвиток, потім - результат "). Світовий досвід свідчить про те, що для створення умов поступового розвитку різнобічних якостей юних гравців, необхідно: по-перше, відмовитися від участі в офіційних змаганнях до 12 років, щоб зробити акцент на якість і ефективність тренувального процесу, спрямованого на індивідуальне розвиток і підготовку креативного гравия; по-друге, проводити навчально-тренувальні заняття в ігровій формі на високому емоційному рівні з обов'язковим урахуванням вікових та індивідуальних особливостей дітей. Саме застосування ігрового методу є ключовим моментом для ефективного навчання, в процесі якого розвиваються індивідуальні можливості, формується ігровий інтелект, закладаються основи техніко-тактичної майстерності дитини, які в подальшому будуть визначати потениіал гравия на професійному рівні.

Ключові слова: «природа» дитячого футтболу, Союз європейських футбольних асоціацій, офріційні змагання, ефрективність тренувального процесу, ігровий метод.

Problem statement. In the 1980s, experts from several countries with developed football, realizing that street football was a thing of the past, came to the conclusion that it was necessary to revise the system of training young talents and provide children with the opportunity to train and play according to their own rules, that is, return to the "nature" of children's football, Vargas F.S., (2005), Michels R., (2001), Ruiz L., (2002).

In particular, the technical department of the Royal Football Union of the Netherlands since 1985 began to look for an alternative to "street" football, realizing that "street" football was the most natural training system that can be found, Kormelink $\mathrm{H}$., 
(1997). Over time, requirements were developed for the organization of the training process with young football players six to twelve years old, which reduced to the following, Van Lingen B., (1998):

- training should take the form of a game. You should not conduct classes aimed at teaching technical skills or the development of motor abilities, as well as working on what the player is unlikely to encounter on the field during the game;

- a children's trainer should offer various game options $(5 \times 2,4 \times 2,6 \times 3$, etc.) from the simplest to the most difficult, taking into account not the calendar, but the "football" age (level of skill and preparedness);

- in addition to three hourly lessons, players should be given a "homework" weekly to practice the techniques;

- games $4 \times 4$ (6-8 years), $7 \times 7$ (9-10 years), $9 \times 9$ (11-12 years) $11 \times 11$

(13 years and older) should be considered as a means of developing children's ball possession skills in solving game problems;

- the team must have trainers specially trained for working with youth;

- a training should take place in a favorable atmosphere, gives pleasure and contribute to the formation of positive character traits in children;

- as far as there are very few innate talents, coaches of youth teams need to pay attention to each player who, with proper training, can become a good football player. Particular attention is given to "reserve players". From a social point of view, this is the most important group. After their active sports career, they can become referees, board members or just loyal people. They are indispensable for any club. Therefore, in clubs, especially today, it is necessary to take care of maintaining a favorable social climate.

Analysis of topical researches. A similar approach has been widely used in Spain, where the training and development of young football players from seven to 15 years old is carried out through a large number of training and educational games. In addition to this (in particular, in FC Barcelona), in the activities with children, the education of the individual (in terms of human qualities) is in the foreground, general education is in the second, and football training is only in the third. Hence the main criteria for the coach to work with teams under 15 years old is his pedagogical abilities, the ability to prepare a football player, the ability to train, Guia Metodologica Del Programa De Formacion Del Barcelona F.C., (2014), Vargas F. S., (2005).

It should be added that in a progressive football community, the rules are followed: the coach is for players, not players for a coach. Do not suppress a personality, but develop it. The main stake is on the development of a vibrant personality. Here, the coach cannot afford to offend the player. Even training tasks are not given to players in an ordered tone, but they explain what purpose they serve and what effect they give. Thinking, developed personalities are always stronger than submissive performers. After all, it is they who make their trainers bad or good, Cale A., (2004), Carney J., (2002).

The renowned German specialist H.Wein, (2004) developed the children's program "FUNino", or, as it is called in many countries of the world, the "Renaissance of street football", for teaching children under ten years of age. He proposed more than 30 versions of this game where children play on a 32x25-meter court with four gates on each sideline. Two teams of three players and one with a substitution take part. The goal can be scored from within the six-meter zone. The goal of the game is to increase intelligence, develop creativity and analyze game situations young football players learn very quickly, because the game situations are repeated regularly, and all the children are constantly involved in the training process.

Numerous studies have found that with a smaller format of the game, children perform more touches of the ball, dribbling and shots on goal, more transitions from attack to defense and back, and a simplified tactical environment makes the decision-making process easier and the game visually understandable for children Almeida C.H., (2012), Andriatti P.E., (2009).

Presentation of the main material. The ideas of famous sports specialists I. Balyi, (2001) and Michels R., (2001), set forth in the athlete's long-term development programs and containing the provision that young children should not participate in competitions where tables are kept and distribution of places between participants are supposed, were found reflected in the progressive football community, Ruiz L., (2002), Talentförderprogramm, (2002).

Currently, the football federations of Australia, England, Germany, the Netherlands, Spain, Portugal, the USA, Scotland and others have officially banned the participation of children under 12 years old in regular competitions, Baan R., (2011), Van Lingen B., (1998). For example, the AFC Ajax program explicitly states that the result as such is completely irrelevant for players under 13 years of age. Coaches are guided by the fact that only in older age groups can the opponent's strength be taken into account when determining the composition of their team, however, even in such games, they must adhere to the club's philosophy of playing - to play creative and attacking football, Kormelink $\mathrm{H}_{\text {,. (1997). }}$

Moreover, when licensing football clubs, the Union of European Football Associations (UEFA) defined the requirements for the development of training programs for young football players based on strategic tasks, where the priority is given to the individual development of the player, and the achievement of sports results is secondary ("development first, then the result.") UEFA Club Licensing System Manual (2006).

The actions taken by the English Football Association (FA), which prepared a strategic plan for the development of youth football, aimed at quality training of players and attracting a large number of children to the classes, The FA Group Strategic Plan (2010), The FA Youth Development Review (2010) are also indicative. )

Implementation of the plan will be phased. The changes will affect the leveling of the significance of the result and determination of the optimal number of teams of participants in the competition (Tables 1 and 2), which will be held over a threefour-year period.

In England, the participation of children under 12 years old in regular competitions was officially prohibited. The main changes occurred in the 2014-2015 season, when players seven and eight years old played in 5x5 format, and teenagers aged 11,12 and 13 years old played in 9x9 format. Their Game Youth Football Development U7 - U8 (2012), Their Game Youth Football Development U9 - U10 (2012), Their Game Youth Football Development U11 - U12 (2012). 
Table 1. Scheme of participation of children in football competitions in England

The FA Group Strategic Plan (2010)

\begin{tabular}{|c|c|c|c|}
\hline Season $2013 / 2014$ & Season 2014/2015 & Season $2015 / 2016$ & Season $2016 / 2017$ \\
\hline $\begin{array}{l}\text { Children under } 7 \text { years old } \\
\text { No tables }\end{array}$ & $\begin{array}{l}\text { Children under } 7 \text { years old } \\
\text { No tables }\end{array}$ & $\begin{array}{l}\text { Children under } 7 \text { years old } \\
\text { No tables }\end{array}$ & $\begin{array}{l}\text { Children under } 7 \text { years old } \\
\text { No tables }\end{array}$ \\
\hline $\begin{array}{l}\text { Children under } 8 \text { years old } \\
\text { No tables }\end{array}$ & $\begin{array}{l}\text { Children under } 8 \text { years old } \\
\text { No tables }\end{array}$ & $\begin{array}{l}\text { Children under } 8 \text { years old } \\
\text { No tables }\end{array}$ & $\begin{array}{l}\text { Children under } 8 \text { years old } \\
\text { No tables }\end{array}$ \\
\hline $\begin{array}{l}\text { Children under } 9 \text { years old } \\
\text { No tables }\end{array}$ & $\begin{array}{l}\text { Children under } 9 \text { years old } \\
\text { No tables }\end{array}$ & $\begin{array}{l}\text { Children under } 9 \text { years old } \\
\text { No tables }\end{array}$ & $\begin{array}{l}\text { Children under } 9 \text { years old } \\
\text { No tables }\end{array}$ \\
\hline $\begin{array}{l}\text { Children under } 10 \text { years old } \\
\text { League Tables }\end{array}$ & $\begin{array}{l}\text { Children under } 10 \text { years old } \\
\text { League Tables }\end{array}$ & $\begin{array}{l}\text { Children under } 10 \text { years old } \\
\text { League Tables }\end{array}$ & $\begin{array}{l}\text { Children under } 10 \text { years old } \\
\text { League Tables }\end{array}$ \\
\hline $\begin{array}{l}\text { Children under } 11 \text { years old } \\
\text { League Tables }\end{array}$ & $\begin{array}{l}\text { Children under } 11 \text { years old } \\
\text { League Tables }\end{array}$ & $\begin{array}{l}\text { Children under } 11 \text { years old } \\
\text { League Tables }\end{array}$ & $\begin{array}{l}\text { Children under } 11 \text { years old } \\
\text { League Tables }\end{array}$ \\
\hline $\begin{array}{l}\text { Children under } 12 \text { years old } \\
\text { League Tables }\end{array}$ & $\begin{array}{l}\text { Children under } 12 \text { years old } \\
\text { League Tables }\end{array}$ & $\begin{array}{l}\text { Children under } 12 \text { years old } \\
\text { League Tables }\end{array}$ & $\begin{array}{l}\text { Children under } 12 \text { years old } \\
\text { No tables }\end{array}$ \\
\hline
\end{tabular}

Among experts, it is widely believed that football is a very difficult game, where a large number of tactical decisions are possible only in games on large fields. Despite this, when teaching the game of football, in order for the process to be effective, it is necessary to move gradually step by step in accordance with the age characteristics of the children, and not quickly "immerse" the children in adult football.

It is a known fact that children under 14 years of age do not usually experience significant growth spurts and are not yet ripe for playing in large fields, Barbero Á. J. C., (2007). Thus, when changing the game of indoor football at the age of ten to the $11 \times 11$ format at 11 years, the goal parameters increase by $265 \%$, and the fields increase to $400 \%$, while the fastest growing children add only $5 \mathrm{~cm}$ in growth in a few months, Rodríguez-Marroyo J.A., (2009).

Table 2. The number of teams participating in children's football competitions in England The FA Group Strategic Plan (2010)

\begin{tabular}{|c|c|c|}
\hline Season $2013-2014$ & Season $2014-2015$ & Season 2015-2016 \\
\hline up to 7 years old $5 \times 5$ & up to 7 years old $5 \times 5$ & up to 7 years old $5 \times 5$ \\
\hline up to 8 years old $7 \times 7$ & up to 8 years old $5 \times 5$ & up to 7 years old $5 \times 5$ \\
\hline up to 9 years old $7 \times 7$ & up to 9 years old $7 \times 7$ & up to 9 years old $7 \times 7$ \\
\hline up to 10 years old $7 \times 7$ & up to 10 years old $7 \times 7$ & up to 10 years old $7 \times 7$ \\
\hline under 11 years old $9 \times 9$ & under 10 years old $9 \times 9$ & under 10 years old $9 \times 9$ \\
\hline under 12 years old $9 \times 9$ or $11 \times 11$ & under 12 years old $9 \times 9$ & under 12 years old $9 \times 9$ \\
\hline under 13 years old $11 \times 11$ & under 13 years old $9 \times 9$ or $11 \times 11$ & under 13 years old $9 \times 9$ \\
\hline
\end{tabular}

Note. The maximum size, but you can play in smaller team squads.

It is another important point. Overcoming long distances, young players do too much anaerobic work, which leads to an increase in heart rate to a level corresponding to the signs of a "diastole defect". It is believed that as a result of a decrease in the duration of diastole, myocardial blood supply is disturbed, and hypoxia causes the development of anaerobic glycolysis. Accumulation of hydrogen ions in the myocardium to the optimal concentration stimulates myocardial cell hypertrophy, and if the duration of the action of such or a higher concentration of hydrogen ions in the myocardium is too long, catabolic reactions can develop. Thus, when conducting games in large fields, conditions are created for the appearance of signs of myocardial dystrophy, Seluyanov V.N., (2012), Capranica L., (2001).

FA's next step was to ban the eight-month competition season for children 7-11 years old. At the same time, a flexible system for conducting children's competitions was proposed. This approach is based on the educational model of learning, in which children are involved in the learning process with in-session participation in games and festivals, where the result fades into the background, and individuality, development of the child's creative abilities, and satisfaction of his needs come first. The FA Youth Development Review, (2010). In the new competition structure, the season will be divided into three parts, each of which ends with a tournament or festival. The duration of each part will increase as the children get older. Thus, children of seven and eight years will participate in two-week, nine and ten years - in four-week, and eleven-year-olds in six-week Developing football for everyone (2011) tournaments.

Instead of a long championship, it is more expedient to organize short tournaments - for one, two, three days or more. This structure of the competition reduces the significance of the final result, and, as a result, the children do not get nervous, relax and increase their creative potential. Thus, a flexible competition system will allow managers and trainers to be creative in their learning process and thereby better meet the needs of children and reduce the impact on them of the established mentality expressed in the motto "win at all costs" The FA Youth Development Review, (2010), Eskandarian A ., (2012).

Football Academy Manager F.C. Liverpool Frank Skelly notes: "Not only in Liverpool, but in all the academies of the Premier League clubs, children under the age of twelve are prohibited from playing in regular tournaments, where there are tables and distribution of seats. Work on the result can psychologically break a young man who at this age, individual qualities need to be developed. Pupils are allowed to play only in friendly matches with other academies, and their number for the season should not exceed 30. This is the academy that gave the world Gerard and Owen (2014).

In addition, a player who has signed a contract with the Academy is guaranteed to play at least 24 games a year. It should be noted that FA exercises strict control over the competitive activity of young football players, regulating the number of matches played (Table 3.). 
Table 3. Competitive practice mode for young football players in England Youth Development Rules (2013)

\begin{tabular}{|c|c|}
\hline Age, years & Number of games per season \\
\hline $9-11$ & $18-30$ (all in small fields) \\
\hline $12-16$ & $18-30$ \\
\hline $17-21$ & $24-42$ \\
\hline
\end{tabular}

A similar method has long been used in FC Barcelona. Pupils of the club in the year-round championship begin to play from 12-13 years old, participating only in short tournaments Guia Metodologica Del Programa De Formacion Del Barcelona F.C., (2014), Vargas F. S., (2005). One should dwell on such a phenomenon as the "effect of relative age". Unfortunately, in all sports the influence of the calendar date of birth of the child takes place. So, children born at the beginning of the calendar year have a clear advantage over those born at the end of the year. It was found that more than $80 \%$ of children who fell into elite (professional) sport were born in the first three months of the year, and less than $10 \%$ were born in the last three months of Martin R. P., (2004), Morris J. G., (2006). In particular, in football, children born in winter have 4 times more chances to achieve sporting successes than their peers born in September and December. If we take this moment into account, we will be able to save up to $50-70 \%$ of all promising children, and not use the existing competition system from an early age, Lesma M. L., (2011), Simmons C., (2001).

The Scottish Football Federation has proposed its reaction against the "relative age effect" by moving from a calendar year to a school year. The result of these changes was an increase in the number of children playing football and the retention of children born in the summer of Scottich FA in football, (2010), McLeish H., (2010).

And yet, the easiest and most effective way to influence the "effect of relative age" is to cancel official competitions up to 12 years old, and ideally - until mid-adolescence. Thus, when victory is less important than development, all players will receive an equal opportunity to play and better training.

It is important to note that the long-term program for training football talent in Western Europe has a common periodization structure. Thus, in Germany and Spain, the process of training football players is divided into two periods, in accordance with which the priorities of the Guia Metodologica Del Programa De Formacion Del Barcelona F.C. (2014), Oscar P. (2012):

- the period of development and training (7-15 years) ensures the development of individual abilities of young football players through the use of a large number of game tasks, training and educational games;

- the competition period (from 16 years to a professional team) ensures the development of the game potential of each player through active participation in games for the result.

Such a practical approach in football fully corresponds to the key provisions of the theory of periodization of sports training, Platonov V.N., (2013). It is clear that each country, each club has its own subtleties and differences associated with both historical and cultural traditions, Report on Youth Academies in Europe (2012). This is reflected in the preparation and selection. There is such a conceptual approach to the training of young football players, which is the abbreviation "TIPS": "technique, intuition, personality, speed." For example, the Spaniards (and they put this in the first place) when selecting guys for teams of an older level have an understanding of the game Problems in Geometry - FC Barcelona football school (Spain) (2014). The Dutch have technical equipment. Starting from the 1990s, FC "Ajax" pays great attention to how a football player works with the ball, to the speed and focus of a young player on achieving victory, Michels R. (2001), Kormelink H. (1997). But among Italians, the most important aspect of upbringing is the clear implementation of game discipline, and they are actively starting to practice tactics at the age of 14-15. This can be seen by watching the ACF Fiorentina training. A very strict implementation of the trainer's instructions plus everything is a modern scientific approach to the training process, Arcelli E. Calcio (2004).

It is worth stopping at the philosophical approach to physical training, adopted in the Netherlands, which boils down to the fact that in the process of physical preparation the main focus is on the work of muscles through the understanding of the fact that muscles execute commands sent by the brain. Muscles are not able to learn, unlike the brain. It is incorrect to argue that players will play better if their lung capacity is increased, or it is better to play their head if the strength of the leg muscles increases. In order to learn how to play football at a good level, you do not need to simplify football to the level of physical activity, but you need to focus on solving motor problems in the process of playing soccer. If the player knows how to solve game situations, then his brain will adequately control the muscles. The more experience a player has in solving situational problems, the faster he makes the right decision.

Therefore, the task of physical preparation is to improve the quality of the game of football, Van Lingen B. (1998), Wein H. (2011).

When assessing the effectiveness of the game, the level of physical fitness of the player is always taken into account. For example:

audience;

ability to solve problems faster, over a long period of time, under pressure from the opponent and the

ability to pressure, play extraordinary, move from defense to attack and vice versa.

The coach must know the basics of physical fitness, choose the right training tools (table. 3.1), which are reduced, first of all, to create such game situations that will encourage players to perform actions better, more often or faster. The quality of the game is based on the ever-increasing difficulty in completing motor tasks. It is necessary to give the players with a challenge that they must willingly accept. Evaluation of the effectiveness of such motor tasks will not consist of heart rate, distance covered, kilograms or minutes, but the player's ability to complete the task, Michels R. (2001). 
Table 4. Regulation of the orientation of the training load, Michels R. (2001)

\begin{tabular}{|l|l|}
\hline \multicolumn{1}{|c|}{ Methodological conditions } & \multicolumn{1}{c|}{ Effect } \\
\hline Reducing the size of the playing space & Less time to make a decision \\
\hline Increase the size of the playing space & More time, longer distances for running and passing the ball \\
\hline More competitors & Less time, harder to "read" the game \\
\hline Less competitors & More time, easier to "read"the game \\
\hline Opponent pressing & Less time, harder to "read" the game \\
\hline Using "Offside" & Less space, less time \\
\hline A sufficient number of balls outside the playing pitch & Continuous play \\
\hline To score balls only with your head & Play winger and a lot of head game \\
\hline Time limit (play only 5 min, last minute) & $\begin{array}{l}\text { Players are forced to more effectively attack, fight for the ball, } \\
\text { control the ball, etc. }\end{array}$ \\
\hline
\end{tabular}

Conclusions. The analysis of literary sources and the generalization of the practical experience of training athletes in team sports games, and in particular in football, indicate the presence of a large number of scientific knowledge on various aspects of the process of many years of player development. However, these data are disparate in nature, are not integrated into an integrated system, which complicates their implementation in the process of many years of improvement of athletes. The studies do not fully take into account that the training of qualified football players is a long, multi-stage process, the content of which should be subject to the creation of conditions for the full realization of the natural inclinations and individual capabilities of young athletes, taking into account the requirements of modern high-speed football. World experience shows that in order to create conditions for the gradual development of the diverse qualities of young players, it is necessary: firstly, to refuse to participate in official competitions up to 12 years old in order to focus on the quality and effectiveness of the training process aimed at individual development and training of a creative player; secondly, to hold training sessions in a game form on a high emotional background with the obligatory consideration of age and individual characteristics of children. It is the application of the game method that is the key to effective learning, during which individual opportunities develop, game intelligence is formed, the foundations of the child's technical and tactical skills are laid, which in the future will determine the player's potential at a professional level.

The results can be used as the basis for research on the scientific substantiation of approaches to adapting the experience of leading countries in organizing the training process and holding children's competitions to the conditions of other countries.

\section{References}

1. Kormelink H. The Dutch Coaching Notebook: The Ultimate Companion For All Ages / H. Kormelink, T. Seeverens: bfp Versand, onLi Verlag, $1997 . \quad-104$ p.

2.Van Lingen B. Coaching Soccer: The Official Coaching Book of the Dutch Soccer Association / B.Van Lingen. Michigan: Reedswain Inc., $1998 . \quad-218$ p.

3.Guia Metodologica Del Programa De Formacion Del Barcelona F.C. : [Electronic resource]. - Access mode: http: // www.futbolentrenamientostenerife. blogspot.com/2014/05/fc-barcelona-organizacion-de-la-base.html

4.Vargas F. S. Fundamental Movement Skills and Their Application to Sports Initiation: Document of the INEFC de Barcelona / F. S. Vargas. - Barcelona The Instituto Nacional de Educación Física de Barcelona University of Barcelona, 2005. $27 \mathrm{p}$.

5.Michels R. Team Building The Road to Success / R. Michels: Cardinal Publishing Group, 2001. - 298 p.

6.Ruiz L. Spanish Soccer Coaching Bible: Youth \& Club / L. Ruiz. - Michigan: Reedswain Publishing, 2002. - Vol. 1. $308 p$

7.Cale A. The Official Fa Guide to Psychology for Football / A. Cale: Hodder \& Stoughton, 2004. - 200 p.

8.Carney J. The Art of Coaching Youth Soccer: Match Related Drills and Exercises for Fun and Winning / J. Carney. Michigan: Reedswain Publishing, 2002. - 99 p.

9. Wein H. Futbol a la medida del nino / H. Wein: Gradagymnos, 2004. - Vol.1 - 290 p.

10. Almeida C. H. Manipulating Task Constraints in Small-Sided Soccer Games: Performance Analysis and Practical Implications / C. H. Almeida, $\quad$ A. P. Ferreira, A. Volossovitch // The Open Sports Sciences Journal, $2012 . \quad$ - № 5. - P. 174-180.

11. Andriatti P. E. Futebol -Treinamento Global em Forma de Jogos Reduzidos / P. E. Andriatti. - Jundiaí: Fontoura, 2009. - 144 p.

12. Balyi I. Sport System Building and Long-term Athlete Development in British Columbia / I. Balyi. - Canada: SportsMed BC, 2001. - 194 p.

13. Baan R. Optus Small-Sided Football Handbook Australia / R. Baan: Football Federation Australia, 2011. -

$37 \mathrm{p}$.

14. Kormelink $\mathrm{H}$. The Coaching Philosophies of Louis van Gaal and the Ajax Coaches / H. Kormelink, T. Seeverens: bfp Versand, onLi Verlag, $1997 . \quad-121$ p.

15. UEFA Club Licensing System Manual (Version2.0) / UEFA, 2006. - 286 p.

16. The FA Group Strategic Plan / The Football Association. - London, $2010 . \quad-14$ p.

17. The FA Youth Development Review / the Football Association. - London, 2010. - 34 p.

18. Their Game Youth Football Development U7 - U8 / FA Youth Development Review. - London, 2012. - 30 p. 
19. Their Game Youth Football Development U9 - U10 / FA Youth Development Review. - London, 2012. - 40

p.

20. Their Game Youth Football Development U11-U12 / FA Youth Development Review. - London, 2012. - 40

p.

21. Talentförderprogramm: Leitfaden für die Ausbildung / Deutscher Fussball-Bund. - Munster: PhilippkaSportverlag, 2002. - 289 p.

22. Barbero Á. J. C. Perfil de actividad durante el juego en futbolistas infantiles / Á. J. C. Barbero, Á. V. Barbero, J. Granda // Educación Física y Deportes. - 2007. - N 4. - P. 33-41.

23. Rodríguez-Marroyo J.A. Intensidad de esfuerzo en Fútbol 7 vs Fútbol 11 Intensity of effort in Football 7 and Football 11 / J. A. Rodríguez-Marroyo, R. Pernía, J.G Villa // Educación Física y Deportes. - 2009. - Vol. VIII. - - N 14. - P. 67-70.

24. Seluyanov V. N. Futbol : problemy fizicheskoy $i$ tekhnicheskoy podgotovki [Football: problems of physical and technique training / V. N. Seluyanov, K. S. Sarsaniya, V. A. Zaborov. INTELLEKTiK", 2012. - 160 p.

25. Capranica L. Heart rate and match analysis in pre-pubescent soccer players / L. Capranica, A. Tessitore, L. Guidetti [et al.] // J Sports Sci., 2001. - N 19. - P. 379-84.

26. Developing football for everyone: National Game Strategy 2011-15 / The Football Association. - London, 2011. -30 p.

27. Eskandarian A. Debate ignites over extended Development Academy season / A. Eskandarian // The Shin Guardian. - 2012 (September 07). - P. 6 -8.

28. Martin R. P. Season of birth is related to child retention rates, achievement, and rate of diagnosis of specific LD / R. P. Martin, G. Clanton, K. Moon // Journal of Learning Disabilities, 2004. - N 37(4). - P. 307-317.

29. Morris J. G. Enhancing opportunities for High-level sporting performance: influence of 'relative age'. A sporting chance / J. G. Morris, M. E. Nevill : Loughborough, UK: Institute of Youth Sport, Loughborough University, 2006. - 34 p.

30. Lesma M. L. Relative age effect (RAE) in spanish football league /

González, J. J. Salinero // Journal of Sport and Health Research. - 2011. - N 3(1). - P. 35-46.

31. Simmons C. Season of birth bias in association football / C. Simmons, G. C. Paull // Journal of Sports Science. - 2001. - N 19(9). - P. 677-686.

32. Scottich FA. Developing Talent Plan / the Scottish FA, 2010. - 34 p.

33. McLeish H. Review of Scottish Football: Grassroots, Recreation and Youth Development / H. McLeish. Glasgow: Scottish FA, 2010. -67 p.

34. Oscar P. El juego de posicion Del F. C. Barcelona. Concepto y entrenamiento / P. Oscar, O. Cano. - Vigo: Moreno \& Conde S.L. 2012. - 123 p.

35. Platonov V.N. Podgotovka sportsmenov raznykh stran k Olimpiyskim igram [Training athletes from different countries for the Olympic Games] / V. N. Platonov, YU. A. Pavlenko, V. V. Tomashevskiy - K.: Publ. house of D. Burago, 2012 .$-336 \mathrm{p}$.

36. Report on Youth Academies in Europe: Youth development central for the future of club football / European Club Assocition, 2012. - 163 p.

37. Zadachi po geometrii-futbol'naya shkola FK «Barselona» (Ispaniya) : [Problems in geometry - FC Barcelona football school (Spain): ] [Electronic resource]. - Access mode: http://vachrushev.blogspot.com/2014_02_01_archive.html

38. Kormelink H. Developing Soccer Players: The Dutch Way / H. Kormelink, T. Seeverens: bfp Versand, onLi Verlag, 1997. - 143 p.

39. Arcelli E. Calcio. Preparazione atletica / E. Arcelli, F. Ferretti // IV Edizione. - Milano: Editoriale Sport Italia, 2004. -134 p.

40. Wein H. Spielintelligenz im Fußball - Kindgemäß trainieren / H. Wein. - Aachen: Meyer\&Meyer, 2011. $-368 p$.

41. Youth Development Rules / Football League FA. - London, 2013. - 331p.

42. Komogorova, M., Maksymchuk, B., Bernatska, O., Lukianchuk, S., Gerasymova, I., Popova, O., Matviichuk, T., Solovyov, V., Kalashnik, N., Davydenko, H., Stoliarenko, O., Stoliarenko, O., \& Maksymchuk, I. (2021). Pedagogical Consolidation of Pupil-Athletes Knowledge of Humanities. Revista Romaneasca Pentru Educatie Multidimensionala, 13(1). https://doi.org/10.18662/rrem/13.1/367

43. Melnyk, N., Maksymchuk, B., Gurevych, R., Kalenskyi, A., Dovbnya, S., Groshovenko, O., \& Filonenko, L. (2021). The Establishment and Development of Professional Training for Preschool Teachers in Western European Countries. Revista Romaneasca Pentru Educatie Multidimensionala, 13(1). https://doi.org/10.18662/rrem/13.1/369

44. Nerubasska, A., Palshkov, K., \& Maksymchuk, B. (2020). A Systemic Philosophical Analysis of the Contemporary Society and the Human: New Potential. Postmodern Openings, 11(4), $275-292$. https://doi.org/10.18662/po/11.4/235

45. Maksymchuk, B., Gurevych, R., Matviichuk, T., Surovov, O., Stepanchenko, N., Opushko, N., Sitovskyi, A., Kosynskyi, E., Bogdanyuk, A., Vakoliuk, A., Solovyov, V., \& Maksymchuk, I. (2020a). Training Future Teachers to Organize School Sport. Revista Romaneasca Pentru Educatie Multidimensionala, 12(4), 310-327. https://doi.org/10.18662/rrem/12.4/347

46. Palamarchuk, O., Gurevych, R., Maksymchuk, B., Gerasymova, I., Fushtey, O., Logutina, N., Kalashnik, N., Kylivnyk, A., Haba, I., Matviichuk, T., Solovyov, V., \& Maksymchuk, I. (2020). Studying Innovation as the Factor in Professional 
Self-Development of Specialists in Physical Education and Sport. Revista Romaneasca Pentru Educatie Multidimensionala, 12(4), 118-136. https://doi.org/10.18662/rrem/12.4/337

47. Onishchuk, I., Ikonnikova, M., Antonenko, T., Kharchenko, I., Shestakova, S., Kuzmenko, N., \& Maksymchuk, B. (2020). Characteristics of Foreign Language Education in Foreign Countries and Ways of Applying Foreign Experience in Pedagogical Universities of Ukraine. Revista Romaneasca Pentru Educatie Multidimensionala, 12(3), 44-65. https://doi.org/10.18662/rrem/12.3/308

48. Maksymchuk, B., Matviichuk, T., Solovyov, V., Davydenko, H., Soichuk, R., Khurtenko, O., Groshovenko, O., Stepanchenko, N., Andriychuk, Y., Grygorenko, T., Duka, T., Pidlypniak, I., Gurevych, R., Kuzmenko, V., \& Maksymchuk, I. (2020b). Developing Healthcare Competency in Future Teachers. Revista Romaneasca Pentru Educatie Multidimensionala, 12(3), 24-43. https://doi.org/10.18662/rrem/12.3/307

49. Gerasymova, I., Maksymchuk, B., Bilozerova, M., Chernetska, Yu., Matviichuk, T., Solovyov, V., \& Maksymchuk, I. (2019). Forming professional mobility in future agricultural specialists: the sociohistorical context. Revista $\begin{array}{llllll}\text { Romaneasca } & \text { pentru } & \text { Educatie } & \text { Multidimensionala, } & 11 & \text { (4), }\end{array}$ http://lumenpublishing.com/journals/index.php/rrem/article/view/1604/pdf

50. Sheremet M., Leniv Z., Loboda V., Maksymchuk B. (2019) The development level of smart information criterion for specialists' readiness for inclusion implementation in education. Information Technologies and Learning Tools, 72, 273-285. https://journal.iitta.gov.ua/index.php/itt//article/view/2561

51. Nerubasska, A., Maksymchuk, B. (2020). The Demarkation of Creativity, Talent and Genius in Humans: a $\begin{array}{llllll}\text { Systemic } & \text { Aspect. } & \text { Postmodern } & \text { Openings, } & 11 & \text { (2), }\end{array}$ https://www.lumenpublishing.com/journals/index.php/po/article/view/2625

52. Melnyk, N., Bidyuk, N., Kalenskyi, A., Maksymchuk. B., Bakhmat, N., Matviienko, O., Matviichuk, T., Solovyov, V., Golub, N., \& Maksymchuk, I. (2019). Modely y orhanyzatsyone osobyne profesyonalne obuke vaspytacha u pojedynym zemљama Evropske Unyje y u Ukrajyny [Models and organizational characteristics of preschool teachers' professional training in some EU countries and Ukraine]. Zbornik Instituta za pedagoska istrazivanja, 51(1), 46-93. https://doi.org/10.2298/ZIPI1901046M

53. Bakhmat, N., Maksymchuk, B., Voloshyna, O., Kuzmenko, V., Matviichuk, T., Kovalchuk, A. ... Maksymchuk, I. (2019). Designing cloud-oriented university environment in teacher training of future physical education teachers. Journal of Physical Education and Sport, 19 (4), 1323-1332. http://efsupit.ro/images/stories/august2019/Art\%20192.pdf

54. Behas, L., Maksymchuk, B., Babii, I., Tsymbal-Slatvinska, S., Golub, N., Golub, V. ... Maksymchuk, I. (2019). The influence of tempo rhythmic organization of speech during gaming and theatrical activities on correction of stammering in children. Journal of Physical Education and Sport, 19 (4), 1333-1340. http://efsupit.ro/images/stories/august2019/Art\%20193.pdf

55. Bezliudnyi O., Kravchenko O., Maksymchuk B., Mishchenko M., Maksymchuk, I. (2019) Psycho-correction of burnout syndrome in sports educators (2019). Journal of Physical Education and Sport, 19 (3), Art 230 pp. 1585. http://efsupit.ro/images/stories/septembrie2019/Art\%20230.pdf

56. Halaidiuk, M., Maksymchuk, B., Khurtenko, O., Zuma, I., Korytko, Z., Andrieieva, R. ... Maksymchuk, I. (2018). Teaching approaches in extracurricular physical activities for 12-14-year-old pupils under environmentally unfavourable conditions. Journal of Physical Education and Sport, $18 \quad$ (4), $2284-2291$. http://efsupit.ro/images/stories/decembrie2018/Art\%20344.pdf

57. Maksymchuk, I., Maksymchuk, B., Frytsiuk, V., Matviichuk, T., Demchenko, I., Babii, I. ... Savchuk, I. (2018). Developing pedagogical mastery of future physical education teachers in higher education institutions. Journal of Physical Education and Sport, 18 (2), 810-815. http://efsupit.ro/images/stories/iunie2018/Art\%20119.pdf

58. Sitovskyi A., Maksymchuk B., Kuzmenko V., Nosko Y., Korytko Z., Bahinska O. ... Maksymchuk, I. (2019). Differentiated approach to physical education of adolescents with different speed of biological development (2019). Journal of Physical Education and Sport, Vol.19 (3), Art 222, pp. 1532 - 1543. http://efsupit.ro/images/stories/august2019/Art\%20192.pdf

\section{Reference}

1.Kormelink H. The Dutch Coaching Notebook: The Ultimate Companion For All Ages / H. Kormelink, T. Seeverens: bfp Versand, onLi Verlag, $1997 . \quad-104$ p.

2.Van Lingen B. Coaching Soccer: The Official Coaching Book of the Dutch Soccer Association / B.Van Lingen. Michigan: Reedswain Inc., $1998 . \quad-218$ p.

3. Guia Metodologica Del Programa De Formacion Del Barcelona F.C. : [Электрон. ресурс]. - Режим доступа: http: // www.futbolentrenamientostenerife. blogspot.com/2014/05/fc-barcelona-organizacion-de-la-base.html

4.Vargas F. S. Fundamental Movement Skills and Their Application to Sports Initiation: Document of the INEFC de Barcelona / F. S. Vargas. - Barcelona The Instituto Nacional de Educación Física de Barcelona University of Barcelona, 2005. $27 \mathrm{p}$.

5.Michels R. Team Building The Road to Success / R. Michels: Cardinal Publishing Group, 2001. - 298 p.

6. Ruiz L. Spanish Soccer Coaching Bible: Youth \& Club / L. Ruiz. - Michigan: Reedswain Publishing, 2002. - Vol. 1. -

$308 p$.

7.Cale A. The Official Fa Guide to Psychology for Football / A. Cale: Hodder \& Stoughton, 2004. - 200 p.

8.Carney J. The Art of Coaching Youth Soccer: Match Related Drills and Exercises for Fun and Winning / J. Carney. Michigan: Reedswain Publishing, 2002. - 99 p.

9. Wein H. Futbol a la medida del nino / H. Wein: Gradagymnos, 2004. - Vol.1 - 290 p. 
10. Almeida C. H. Manipulating Task Constraints in Small-Sided Soccer Games: Performance Analysis and Practical Implications / C. H. Almeida, A. P. Ferreira, A. Volossovitch // The Open Sports Sciences Journal, $2012 . \quad$ - № 5. - P. 174-180.

11. Andriatti P. E. Futebol -Treinamento Global em Forma de Jogos Reduzidos / P. E. Andriatti. - Jundiaí: Fontoura, 2009. - 144 p.

12. Balyi I. Sport System Building and Long-term Athlete Development in British Columbia / I. Balyi. - Canada: SportsMed BC, 2001. - 194 p.

13. Baan R. Optus Small-Sided Football Handbook Australia / R. Baan: Football Federation Australia, 2011. $37 \mathrm{p}$.

14. Kormelink $\mathrm{H}$. The Coaching Philosophies of Louis van Gaal and the Ajax Coaches / H. Kormelink, T. Seeverens: bfp Versand, onLi Verlag, $1997 . \quad$ - 121 p.

15. UEFA Club Licensing System Manual (Version2.0) / UEFA, 2006. - $286 \mathrm{p}$.

16. The FA Group Strategic Plan / The Football Association. - London, 2010. - 14 p.

17. The FA Youth Development Review / the Football Association. - London, 2010. - 34 p.

18. Their Game Youth Football Development U7 - U8 / FA Youth Development Review. - London, 2012. - 30 p.

19. Their Game Youth Football Development U9 - U10 / FA Youth Development Review. - London, 2012. - 40

p.

20. Their Game Youth Football Development U11-U12 / FA Youth Development Review. - London, 2012. - 40

p.

21. Talentförderprogramm: Leitfaden für die Ausbildung / Deutscher Fussball-Bund. - Munster: PhilippkaSportverlag, 2002. - 289 p.

22. Barbero Á. J. C. Perfil de actividad durante el juego en futbolistas infantiles / Á. J. C. Barbero, Á. V. Barbero, J. Granda // Educación Física y Deportes. - 2007. - N 4. - P. 33-41.

23. Rodríguez-Marroyo J.A. Intensidad de esfuerzo en Fútbol 7 vs Fútbol 11 Intensity of effort in Football 7 and Football 11 / J. A. Rodríguez-Marroyo, R. Pernía, J.G Villa // Educación Física y Deportes. - 2009. - Vol. VIII. - N 14. - P. 67-70.

24. Селуянов В. Н. Футбол : проблемы физической и технической подготовки / В. Н. Селуянов, К. С. Сарсания, В. А. Заборов.- Долгопрудный : Изд. дом «ИНТЕЛЛЕКТиК», 2012. - 160 с.

25. Capranica L. Heart rate and match analysis in pre-pubescent soccer players / L. Capranica, A. Tessitore, L. Guidetti [et al.] // J Sports Sci., 2001. - N 19. - P. 379-84.

26. Developing football for everyone: National Game Strategy 2011-15 / The Football Association. - London, 2011. $-30 \mathrm{p}$.

27. Eskandarian A. Debate ignites over extended Development Academy season / A. Eskandarian // The Shin Guardian. - 2012 (September 07). - P. 6 - 8.

28. Martin R. P. Season of birth is related to child retention rates, achievement, and rate of diagnosis of specific

LD / R. P. Martin, G. Clanton, K. Moon // Journal of Learning Disabilities, 2004. - N 37(4). - P. 307-317.

29. Morris J. G. Enhancing opportunities for High-level sporting performance: influence of 'relative age'. A sporting chance / J. G. Morris, M. E. Nevill : Loughborough, UK: Institute of Youth Sport, Loughborough University, 2006. - 34 p.

30. Lesma M. L. Relative age effect (RAE) in spanish football league / $\quad$ M. L. Lesma, B. Pérez-

González, J. J. Salinero // Journal of Sport and Health Research. - 2011. - N 3(1). - P. 35-46.

31. Simmons C. Season of birth bias in association football / C. Simmons,

G. C. Paull // Journal of Sports

Science. - 2001. - N 19(9). - P. 677-686.

32. Scottich FA. Developing Talent Plan / the Scottish FA, 2010. - 34 p.

33. McLeish H. Review of Scottish Football: Grassroots, Recreation and Youth Development / H. McLeish. Glasgow: Scottish FA, 2010. -67 p.

34. Oscar P. El juego de posicion Del F. C. Barcelona. Concepto y entrenamiento / P. Oscar, O. Cano. - Vigo: Moreno \& Conde S.L. 2012. - 123 p.

35. Платонов В.Н. Подготовка спортсменов разных стран к Олимпийским играм / В. Н. Платонов, Ю. А. Павленко, В. В. Томашевский - К.: Изд. дом Д. Бураго, 2012. - 336 с.

36. Report on Youth Academies in Europe: Youth development central for the future of club football / European Club Assocition, 2012. - 163 p.

37. Задачи по геометрии-футбольная школа ФК «Барселона» (Испания) : [Электрон. ресурс]. - Режим доступа: http://vachrushev.blogspot.com/2014_02_01_archive.html Verlag, 1997. - $143 p$

38. Kormelink H. Developing Soccer Players: The Dutch Way / H. Kormelink, T. Seeverens: bfp Versand, onLi

39. Arcelli E. Calcio. Preparazione atletica / E. Arcelli, F. Ferretti // IV Edizione. - Milano: Editoriale Sport Italia, 2004. -134 p.

40. Wein H. Spielintelligenz im Fußball - Kindgemäß trainieren / H. Wein. — - Aachen: Meyer\&Meyer, 2011. $-368 p$.

41. Youth Development Rules / Football League FA. - London, 2013. - 331p.

42. Komogorova, M., Maksymchuk, B., Bernatska, O., Lukianchuk, S., Gerasymova, I., Popova, O., Matviichuk, T., Solovyov, V., Kalashnik, N., Davydenko, H., Stoliarenko, O., Stoliarenko, O., \& Maksymchuk, I. (2021). Pedagogical 
Consolidation of Pupil-Athletes Knowledge of Humanities. Revista Romaneasca Pentru Educatie Multidimensionala, 13(1). https://doi.org/10.18662/rrem/13.1/367

43. Melnyk, N., Maksymchuk, B., Gurevych, R., Kalenskyi, A., Dovbnya, S., Groshovenko, O., \& Filonenko, L. (2021). The Establishment and Development of Professional Training for Preschool Teachers in Western European Countries. Revista Romaneasca Pentru Educatie Multidimensionala, 13(1). https://doi.org/10.18662/rrem/13.1/369

44. Nerubasska, A., Palshkov, K., \& Maksymchuk, B. (2020). A Systemic Philosophical Analysis of the Contemporary Society and the Human: New Potential. Postmodern Openings, 11(4), $275-292$. https://doi.org/10.18662/po/11.4/235

45. Maksymchuk, B., Gurevych, R., Matviichuk, T., Surovov, O., Stepanchenko, N., Opushko, N., Sitovskyi, A., Kosynskyi, E., Bogdanyuk, A., Vakoliuk, A., Solovyov, V., \& Maksymchuk, I. (2020a). Training Future Teachers to Organize School Sport. Revista Romaneasca Pentru Educatie Multidimensionala, 12(4), 310-327. https://doi.org/10.18662/rrem/12.4/347

46. Palamarchuk, O., Gurevych, R., Maksymchuk, B., Gerasymova, I., Fushtey, O., Logutina, N., Kalashnik, N., Kylivnyk, A., Haba, I., Matviichuk, T., Solovyov, V., \& Maksymchuk, I. (2020). Studying Innovation as the Factor in Professional Self-Development of Specialists in Physical Education and Sport. Revista Romaneasca Pentru Educatie Multidimensionala, 12(4), 118-136. https://doi.org/10.18662/rrem/12.4/337

47. Onishchuk, I., Ikonnikova, M., Antonenko, T., Kharchenko, I., Shestakova, S., Kuzmenko, N., \& Maksymchuk, B. (2020). Characteristics of Foreign Language Education in Foreign Countries and Ways of Applying Foreign Experience in Pedagogical Universities of Ukraine. Revista Romaneasca Pentru Educatie Multidimensionala, 12(3), 44-65. https://doi.org/10.18662/rrem/12.3/308

48. Maksymchuk, B., Matviichuk, T., Solovyov, V., Davydenko, H., Soichuk, R., Khurtenko, O., Groshovenko, O., Stepanchenko, N., Andriychuk, Y., Grygorenko, T., Duka, T., Pidlypniak, I., Gurevych, R., Kuzmenko, V., \& Maksymchuk, I. (2020b). Developing Healthcare Competency in Future Teachers. Revista Romaneasca Pentru Educatie Multidimensionala, 12(3), 24-43. https://doi.org/10.18662/rrem/12.3/307

49. Gerasymova, I., Maksymchuk, B., Bilozerova, M., Chernetska, Yu., Matviichuk, T., Solovyov, V., \& Maksymchuk, I. (2019). Forming professional mobility in future agricultural specialists: the sociohistorical context. Revista $\begin{array}{llllll}\text { Romaneasca } & \text { pentru } & \text { Educatie } & \text { Multidimensionala, } & 11 & \text { (4), }\end{array}$ http://lumenpublishing.com/journals/index.php/rrem/article/view/1604/pdf

50. Sheremet M., Leniv Z., Loboda V., Maksymchuk B. (2019) The development level of smart information criterion for specialists' readiness for inclusion implementation in education. Information Technologies and Learning Tools, 72 , 273-285. https://journal.iitta.gov.ua/index.php/itt/article/view/2561

51. Nerubasska, A., Maksymchuk, B. (2020). The Demarkation of Creativity, Talent and Genius in Humans: a $\begin{array}{cccccc}\text { Systemic } & \text { Aspect. } & \text { Postmodern } & \text { Openings, } & 11 & \text { (2), }\end{array}$ https://www.lumenpublishing.com/journals/index.php/po/article/view/2625

52. Melnyk, N., Bidyuk, N., Kalenskyi, A., Maksymchuk. B., Bakhmat, N., Matviienko, O., Matviichuk, T., Solovyov, V., Golub, N., \& Maksymchuk, I. (2019). Modely y orhanyzatsyone osobyne profesyonalne obuke vaspytacha u pojedynym zemљama Evropske Unyje y u Ukrajyny [Models and organizational characteristics of preschool teachers' professional training in some EU countries and Ukraine]. Zbornik Instituta za pedagoska istrazivanja, 51(1), 46-93. https://doi.org/10.2298/ZIPI1901046M

53. Bakhmat, N., Maksymchuk, B., Voloshyna, O., Kuzmenko, V., Matviichuk, T., Kovalchuk, A. ... Maksymchuk, I. (2019). Designing cloud-oriented university environment in teacher training of future physical education teachers. Journal of Physical Education and Sport, 19 (4), 1323-1332. http://efsupit.ro/images/stories/august2019/Art\%20192.pdf

54. Behas, L., Maksymchuk, B., Babii, I., Tsymbal-Slatvinska, S., Golub, N., Golub, V. ... Maksymchuk, I. (2019). The influence of tempo rhythmic organization of speech during gaming and theatrical activities on correction of stammering in children. Journal of Physical Education and Sport, 19 (4), 1333-1340. http://efsupit.ro/images/stories/august2019/Art\%20193.pdf

55. Bezliudnyi O., Kravchenko O., Maksymchuk B., Mishchenko M., Maksymchuk, I. (2019) Psycho-correction of burnout syndrome in sports educators (2019). Journal of Physical Education and Sport, 19 (3), Art 230 pp. 1585. http://efsupit.ro/images/stories/septembrie2019/Art\%20230.pdf

56. Halaidiuk, M., Maksymchuk, B., Khurtenko, O., Zuma, I., Korytko, Z., Andrieieva, R. ... Maksymchuk, I. (2018). Teaching approaches in extracurricular physical activities for 12-14-year-old pupils under environmentally unfavourable conditions. Journal of Physical Education and Sport, $18 \quad$ (4), $2284-2291$. http://efsupit.ro/images/stories/decembrie2018/Art\%20344.pdf

57. Maksymchuk, I., Maksymchuk, B., Frytsiuk, V., Matviichuk, T., Demchenko, I., Babii, I. ... Savchuk, I. (2018). Developing pedagogical mastery of future physical education teachers in higher education institutions. Journal of Physical Education and Sport, 18 (2), 810-815. http://efsupit.ro/images/stories/iunie2018/Art\%20119.pdf

58. Sitovskyi A., Maksymchuk B., Kuzmenko V., Nosko Y., Korytko Z., Bahinska O. ... Maksymchuk, I. (2019). Differentiated approach to physical education of adolescents with different speed of biological development (2019). Journal of Physical Education and Sport, Vol.19 (3), Art 222, pp. 1532 - 1543. http://efsupit.ro/images/stories/august2019/Art\%20192.pdf 